\title{
The Application of Interaction Emotion Teaching Method in University Innovation Education
}

\author{
Chunwei Wang \\ Ideological and political Teaching, Xijing University, Shaanxi 710123 China \\ 75700789@qq.com
}

\begin{abstract}
Keywords: Interaction Emotion Teaching Method; Teaching Management Mode; Innovation; Application
\end{abstract}

\begin{abstract}
With the development of the society and colleges and universities, the teaching management work in colleges and universities appears new situation and problems, and the ideas of the students there also gradually develop toward the diversification trend. The large individual differences of the students and the changing of the employment way and the job selection situation both demand that the university management work not only needs institutional constraints and the $\mathrm{e}$ rules of the policy, law and other provisions, but also needs to introduce the interaction emotion teaching method to promote the innovative education of colleges and universities. This article mainly discusses the interactive emotional teaching method of higher education to provide reference for the development of the innovation education of colleges and universities.
\end{abstract}

\section{Introduction}

The teaching management mode is the important link to promote the development of the school and the basis to ensure the education work smoothly. For the development of education, it has the very important practical significance. As an important component of the whole management work in colleges and universities, the educational effect of students education management work plays a serious impact on the development of colleges and universities. With the progress of social economy and the improvement of science and technology of the whole society, students' thought and behavior also begin to change and has brought many new problems for the students teaching management work of higher education. In the process of teaching and management, the interactive emotional teaching method which has very important practical significance for improving the classroom efficiency and the quality of management gets more and more attention of the college teachers. In the daily management and class teaching, to obtain good effect of teaching management and teaching and improve the quality of teaching management and teaching effectiveness, it is important to use the interactive teaching methods emotion for the teachers to form a harmonious and healthy atmosphere. Only with the good management and teaching atmosphere, the students' interest in learning can be inspired, the students' autonomous consciousness can be improved and the communication between students and teachers can achieve a good stage which all not only conducive to establish the relationship between students and teachers, but also bring a lot of convenience to the teaching and management. In this way, the quality of teaching is getting better and better and the management also becomes smoother unconsciously.

\section{Definition of the Interactive Emotional Teaching Method}

The interactive emotion teaching methods refers to that in the process of teaching management; the teachers mobilize students' learning motivation and consciousness of self -management by stimulating the student emotion. At the same time, in the process of teaching management, the emotional exchange and communication brings more content of the emotional perceptual than before which can improve the relationship between teachers and students and make them closer and harmony. This method which combines the emotion with the actual management can lead the student to participate in the self- education management through asking questions, summarize and speculation to the related contents in the teaching management and share their harvest by analyzing 
their own feeling to improve the enthusiasm of students' self -education management and deepen the emotion to the teachers to achieve the goal of improving the teaching management effectiveness when sublimate the students emotion.

The interactive emotional teaching method makes the students participate in the management and fully displays the students' heart from passive to active through mobilizing students' emotion, cultivating the students' subjective initiative and changing the emotions into power. The interactive emotional teaching method reveals the innovation characteristics of modern management mode, expresses the teacher's love and sense of responsibility by the true feelings which can influence the students through emotional communication and bring to life the teaching management atmosphere to improve the efficiency of the teaching management.

\section{The Significance of the Application of Interactive Emotional Teaching Method in Innovative Education of Colleges and Universities.}

The Interactive Emotional Teaching Method is Conducive to Arouse the Enthusiasm of the Students' Self -Education Management. In the process of innovation education in colleges and universities, the interactive emotional teaching method is helpful to inspire and encourage students and makes students have the motivation of self-management and self-learning. For the purpose of inducing the behavior of students, the teachers penetrate and inject emotions to stimulate the students producing the inner power to make efforts toward the goal spontaneously. In particular, the enthusiasm of students is aroused fully by this method. In the process of application of interactive emotional teaching method, the teachers can also establish self-confidence and motivate the subjective initiative for students with the emotional mechanism methods of praise and evaluation to raise the competition consciousness among students and strengthen the relationship between teachers and students which is helpful to create a good teaching management atmosphere.

It is important for the former teaching management mode to pay more attention the management department of colleges and universities and the teaching management mode leading by the teachers where students are in a passive position. Therefore, it is easy to form opposite status between management department and student. In the new period, facing the new problems, it is necessary for the management department of colleges and universities to reform the management thinking and mobilize students' self-management consciousness fully for them participating in the management work to change the original passive situation. The management mode which gives priority to the students' self-management enables students to master the initiative and enhances the enthusiasm of self-management. As the manager and by managers, the student's ability of self-discipline and self-control will be improved. For the interactive emotional teaching method, taking good care of students is the starting point, using the emotional injection as the basic means in the process of teaching management. The teachers should treat every student equally without favoritism, fully demonstrate their love for all students, encourage and praise the underperforming students when they make progress to enhance their self-confidence and self-esteem and improve the students' self-management to improve the management efficiency.

The Interactive Emotional Teaching Method is Conducive to Help College Students Improve the Perfect Personality, Strengthen Self-Confidence and Lay a Solid Foundation for Innovation Education. The interactive emotional teaching method is conducive to help college students improve the perfect personality, Strengthen self-confidence and lay a solid foundation for innovation education.

It is helpful for the interactive emotional teaching method to improve the psychological quality, cultivate the personality, and enhance self-confidence of the students in the process of participating teaching management. In the process of teaching management, the application of it not only can be embodied in a managers' emotional injection but also can improve the psychological quality of students with the improvement of their management consciousness and management quality which plays an important role in cultivating and improving college students' self-management ability. The person who has the ability of self-discipline and management can make greater achievements in social life in the future. In college, the teachers apply the interactive emotional teaching method to 
provide a platform of self-sufficiency for the students where can improve their psychological quality and develop their good positive attitude which will be the basis for the social practice activities when the students enter into the society. The emotion injections not only enhance the students' consciousness of self-management but also enhance their self-confidence to make more achievements in social life in the future. At the same time, it is helpful to lay a good foundation for innovation education.

The Interactive Emotional Teaching Method is Conducive to Improve the Relationship between Teachers and Students and Provide Good Teaching Atmosphere for Innovation Education. The interactive emotional teaching method is beneficial to improve teaching management atmosphere and promote the interaction between teachers and students. It is also can make teachers inject emotion to the students and increase the interaction between teachers and students in the process of the management of students to form teaching management atmosphere which can effectively guarantee the achievement of the teaching management goals smoothly. Good teaching management psychological environment refers to the tacit and harmonious relationship between teachers and students. Only students fully realize the importance of self-management, involve in the management, the enthusiasm of them can be fully mobilized; only the teachers love their jobs, love their students sincerely, the teachers' teaching enthusiasm can be released fully.

So, in the teaching process, teachers should manage the teaching with a heart of caring the students sincerely and understand and respect students to shorten the distance between teachers and students with cooperation and trust. In this way, The teaching management atmosphere becomes harmonious, the teaching management environment becomes loose and the teachers also teach the students how to make emotional communication at the same time. When the teaching atmosphere is improved, it is easier for the education innovation to improve the teaching effectiveness naturally.

\section{The Specific Measures to Improve the University Innovation Education Effectiveness by the Interactive Emotional Teaching Method.}

Enhance the Quality of Students Teaching Management Staff. It is important for the excellent students teaching management team to promote the implementation of the interactive emotional teaching method for the students in colleges and universities and the smooth progress of the management work. At the present stage, the teaching management team in colleges and universities with low self-quality hasn't experienced the professional training and the application of the interactive emotional teaching method is also in the primary stage when a lot of thought education work is borne by non-professional part-time teachers. Therefore, we must pay much attention on the training of college counselor's team for the reason that only improving the whole quality of the teaching management staff; the interactive emotional teaching method can provide service for the management. To make a solid foundation for the widely use of the method, it is necessary to make efforts in the range of business training and staffing and strengthen the professional knowledge and skills of counselors to implement the innovation of the student management work.

Build a Network Management System to Promote the Development of Interactive Emotional Teaching Method with the Help of High-Tech Means. As the important means, the application of high-tech information technology can ensure the successful application of interactive emotional teaching method in the teaching management of college students. The network information tools have played a very important role for the teaching management of college students for its high efficiency and the fresh, curious, dependent psychology of the students to the network. The efficient information communication and interaction between teachers and students can realize by using the modern teaching management methods such as campus BBS and website which can make the students have the right of equality through the simple mode.

Network management has been applied to the various aspects of social life and become an important means of campus management with the rapid development of science and technology and the wide application of Internet. It is necessary for the institutions of higher learning to use new technology to innovative student management work actively. For the reason that the students always accept the new things more easily, counselors in colleges and universities should fully comply with 
the development of The Times and manage the students by the Internet. Firstly, set up and improve the electronic information files to promote the close link between instructors and students and understand and grasp each student's specific ideas dynamically and timely. Secondly, build a network platform and create a positive network public opinion environment which is helpful to lead the students' thoughts correctly. Thirdly, carry out political work education using Internet, reading all kinds of students' ideological education hot topic at home and abroad and absorb and draw lessons from the advanced rules and regulations in domestic and foreign to raise awareness. Fourthly, Establish a communication platform by the Internet, carry out and targeted psychological consultation activities in view of the student's thought to build a bridge between students and counselors and between parents and counselors which is conducive to the relation and communication among students, colleges and universities, parents and the innovation of the student management work effectively.

The new management mode can be accepted by students more easily than the old one which can embody the innovation of interactive emotional teaching method in the teaching management of colleges and universities.

Permeate the Humanistic Management Thinking in the Teaching Management. In order to obtain the ideal effect, interactive emotional teaching method demands that the teaching managers of colleges and universities must change the idea and establish people-oriented management thinking. The transition of the management thought is mainly embodied in two specific aspects:

First of all, during the teaching management, the style of management mode must be changed from authoritative into conversational. Managers should know that the ordering management method whose effect is far less than the interactive emotional teaching method already cannot adapt to the characteristics of student management at present stage. It means that the outdated old management method should be eliminated by laying down their shelves, making friends with the student friends, being a good listener, coming into close contact with the students, blending into the student's heart, feeling the feelings of the students, and paying attention to the students' life. Manage and educate the students according to their different characteristics and their aptitude by embracing affection and reasoning to establish the deep emotional communication with students and shape the new relationship between teachers and students which is convincing.

Secondly, managers mustn't limit the students excessively and should change the management method from limitation type to developing type by learning to treat the students in the view of developing, learning the perspective-taking, reducing the accused, increasing tolerance and being kind to the students. Only put themselves in the students' place, the managers can be able to build a communication bridge between the teachers and students.

\section{Conclusion}

Based on the above, the application of the interactive of emotional teaching method in the teaching management in colleges and universities will create a new road for the college teaching management model innovation which has a very important practical significance for the improvement of university innovation education effectiveness. The organic combination of the Interactive emotional teaching method and the rigid management mode will improve the university innovation education level to a new stage. The emotional injection of the interactive emotional teaching method is more flexible, efficient, practical and scientific which can enhance the communication and collaboration between managers and by managers to improve the teaching management of atmosphere and the overall university innovation education effectiveness.

\section{References}

[1] Wang Feng mei, The Research on the Application of 'Combination of Emotion and Interaction' Teaching Method in Basic Computer Courses in University, Journal of Hunan Institute of Technology, 2013 
[2] Yang Wei jie, The Research on the Application of Interaction Teaching in Ideological and Political Courses in Universities, Education Science \& Culture Magazine Ten-day, 2015

[3] Wei De cai, Cheng Qian, The Research on the Application of Multimedia Technology in Professional Courses Teaching of Colleges and Universities under the Innovative Teaching Mode, Journal of Hunan Post and Telecommunication College, 2015

[4] Xiao Xing guo, Build a Multidimensional Interaction, New Efficient Multimedia Teaching Classroom-The Research on the Ideological and Political Theory Class Teaching Method Innovation, Journal of Shaoyang University, Science Edition, 20128 Thesis Album of Education Teaching Reform of Shaoyang University, 2012

[5] WANG Zhi jun, Yu Chang, Innovation in colleges and universities entrepreneurship education model research [J]. Journal of academic BBS, 2013.12.

[6] HUANG Xing hai, Innovation entrepreneurship education practice teaching mechanism analysis [J]. Journal of heilongjiang province higher education research, 2015.11.

[7] CHAI Jian, WANG xiao-fei, Try to talk about innovation is an important characteristic of higher education: knowledge view perspective $[\mathrm{J}]$. Journal of chongqing higher education research, 2013, 1 (2) : 96-98.

[8] ZHOU Xu, Teaching method of the dilemma and its breakthrough in the university classroom, and theory $[\mathrm{J}]$. Journal of cultivating creative personnel in colleges and universities of sichuan normal university (social science edition), and 2015 (1) : 82-88.

[9] HUANG Yong rong, HE Heng yu, DING Lili, Based on the curriculum reform in colleges and universities study of improving the practical ability of university students [J]. Journal of heilongjiang province higher education research, 2014 (5) : 153-155.

[10]LIANG Xiao yi, ZHAO Zheng zeng, XU Chun Qu, University of innovative talents cultivation of restricting factors and countermeasures [J]. Journal of education theory and practice, 2013 (27): 12-14. 